\title{
PERBANDINGAN KOMUNIKASI NONVERBAL PENUTUR ASLI DAN PENUTUR ASING BAHASA INGGRIS DALAM PUBLIC SPEAKING
}

\author{
${ }^{1}$ I Made Suta Paramarta, ${ }^{2}$ Putu Ayu Prabawati Sudana \\ 1,2 Jurusan DIII Bahasa Inggris, \\ Universitas Pendidikan Ganesha, Singaraja, Indonesia \\ e-mail: imadesutaparamarta@gmail.com, \\ ayuprabawati@yahoo.com
}

\begin{abstract}
Abstrak
Tujuan penelitian ini adalah untuk membandingkan fitur-fitur nonverbal penutur asli dan penutur asing dalam public speaking. Perbedaan budaya antara kedua kelompok penutur tersebut menimbulkan perbedaan penggunaan fitur nonverbal dalam public speaking. Desain penelitian ini adalah desain deskriptif kualitatif dengan 10 subjek. 5 subjek adalah video penutur asli Bahasa Inggris dan 5 video subjek yang lain adalah video mahasiswa Jurusan D III Bahasa Inggris Universitas Pendidikan Ganesha. Penutur asli menunjukkan gerakan nonverbal yang jauh lebih variatif dari penutur asing Bahasa Inggris. Penutur asli memiliki gerakangerakan spesifik yang mengacu pada makna yang spesifik juga. Di lain pihak, penutur asing menunjukkan gerakan nonverbal yang bersifat umum tanpa rujukan pasti pada maksud yang spesifik. Fitur nonverbal yang dicermati dikelompokkan pada gerakan kepala, gerakan badan, dan kontak mata.
\end{abstract}

Kata kunci: perbandingan, nonverbal, public speaking

\begin{abstract}
The purpose of this research is to compare the nonverbal features of the native speakers and the non-native speakers of English in public speaking. Cultural differences between the two groups make significant differences on using the nonverbal features in public speaking. The design of this research was a descriptive-qualitative design with 10 subjects. 5 subjects were videos of 5 English native speakers and the other 5 subjects were the videos of 5 students of Diploma III English Department Universitas Pendidikan Ganesha. The native speakers showed more variative nonverbal movements compared to the non-native speakers. The native speakers made specific gestures which refered to certain specific meanings. On the other hand, the non-native speakers applied general nonverbal movements without specific referents. The investigated nonverbal features were grouped into head movements, body movements, and eye contacts.
\end{abstract}

Keywords: comparison, nonverbal, public speaking 


\section{PENDAHULUAN}

Public speaking merupakan salah satu bentuk komunikasi yang memadukan aspek komunikasi verbal dan nonverbal. Di dalamnya, transfer pesan dilakukan utamanya dengan komunikasi verbal. Namun, penggunaan komunikasi nonverbal juga sangat berperan dalam membantu hadirin dalam memahami pesan yang tersirat dan tersurat (Huang, 2011., Zhan, 2012). Kombinasi antara komunikasi verbal dan nonverbal akan sangat efektif dalam mempresentasikan pesan dalam public speaking (Mulyana, 2007: 141). Penggunaan komunikasi nonverbal sangat berkaitan dengan kebiasaan penutur bahasa yang dilatarbelakangi oleh budaya masyarakat dimana penutur tinggal (Tian, 2010). Dalam public speaking, sebagaimana dalam komunikasi yang lain, penutur asli Bahasa Inggris memakai komunikasi nonverbal yang berbeda dengan penutur bahasa Indonesia. Penutur asli Bahasa Inggris, memiliki kecenderungan lebih ekspresif dan variatif dalam penggunaan komunikasi nonverbal dibandingkan dengan orang Indonesia yang belum mengadopsi budaya barat (Miguel \& Dols, 2013). Setiap ujaran selalu dikombinasikan dengan gerakan anggota tubuh, ekpresi wajah, dan kontak mata yang selalu mengarah ke hadirin. Hal berbeda terjadi di Indonesia, khususnya di Bali. Suandi (2010: 21) menemukan bahwa dalam berkomunikasi publik (public speaking), yaitu rapat adat dan penangkilan, hanya sebagian kecil dari tuturan para responden penelitiannya disertai dengan gerak-gerik. Masih ada sedikit responden dalam penelitiannya yang menanggapi negatif penggunaan gerakgerik lawan bicara.

Sehubungan

dengan

penggunaan bahasa dalam suatu masyarakat yang tidak bisa dipisahkan dengan budayanya, fenomena menarik terjadi ketika orang Bali berpidato dalam Bahasa Inggris,. Mereka harus bisa melepaskan diri dari belenggu gaya bicara orang Bali, dan mengadopsi gaya bicara penutur asli Bahasa Inggris supaya presentasi mereka natural. Secara lebih khusus, di jurusan Diploma III Bahasa Inggris Undiksha, pidato (Speech) atau public speaking sudah menjadi salah satu keterampilan yang diberikan kepada para mahasiswa. Dalam perkuliahan ini, para mahasiswa diajarkan untuk berbicara di depan hadirin dalam bahasa Inggris dengan kombinasi komunikasi verbal dan nonverbal yang baik dan natural dari sudut pandang penutur asli Bahasa Inggris, bukan dari sudut pandang penutur Bahasa Bali atau Indonesia. Dari sudut karakteristik mahasiswa, ditemukan bahwa, para mahasiswa belum pernah tinggal di negara-negara yang memakai Bahasa Inggris sebagai bahasa pertama, sehingga mereka belum memiliki 'nilai rasa' terhadap penggunaan aspek verbal dan nonverbal penutur asli secara menyeluruh. Mereka hanya mengikuti mata kuliah Cross Cultural Understanding dan mata kuliah keterampilan berbahasa produktif dan reseptif pada atmosfer English as a Foreign Language, di mana seting belajar tidak berlokasi pada daerah yang penduduknya berbahasa Inggris sebagai bahasa sehari-hari. Keunikan fenomena di atas secara teoritis berhubungan erat dengan pendapat 
Gao (2013:1429-1433) yang menyatakan bahwa bahasa adalah produk dan komponen dari suatu budaya. Selain itu bahasa merupakan carrier dari sebuah budaya, yang keduaduanya saling mendukung. Bahasa merefleksikan karakteristik sebuah bangsa, meliputi sejarah dan latar belakang budaya, model berpikir orang, tingkah laku sosial, dan cara-cara sosial. Bahkan ada kesimpulan bahwa tidak ada budaya tanpa adanya bahasa.

Dengan latar belakang pemikiran perbedaan budaya tersebut maka dilaksanakanlah sebuah penelitian deskriptif dengan tujuan untuk menganalisis perbedaan penggunaan strategi nonverbal penutur asli dan penutur asing Bahasa Inggris dalam mempresentasikan berbicara di depan publik.

\section{METODE}

Penelitian ini menggunakan pendekatan deskriptif-kualitatif. Rancangan ini menerapkan teori untuk membatasi arah penelitian ke suatu fokus permasalahan yang sudah disasar sejak awal (Sutopo, 2006 : 139). Dalam menganalisis, batasan tersebut tidak menutup kemungkinan peneliti berpikir menyeluruh karena masih terdapat kemungkinan untuk munculnya variabel lain yang berhubungan dengan permasalahan penelitian sebagai variabel utamanya. Terdapat dua kelompok subjek penelitian yaitu video penutur asli Bahasa Inggris yang berjumlah 5 video dari 5 orang berbeda dan 5 video presentasi public speaking dari 5 orang mahasiswa Jurusan D III Bahasa Inggris Universitas Pendidikan Ganesha. Para mahasiswa diminta mempresentasikan naskah public speaking yang sama dengan yang dipresentasikan oleh penutur asli. Hal ini dilakukan untuk memudahkan melihat perbedaan penggunaan komunikasi nonverbal mereka ketika menyampaikan hal yang sama. Presentasi public speaking penutur asli diunduh dari WWW. TED.COM dan kemudian presentasi mahasiswa direkam setelah diberikan waktu memahami dengan baik teks public speaking yang diberikan. Proses analisis video dilakukan dengan menggunakan program ELAN untuk melihat secara detail gerakan nonverbal yang ditunjukkan oleh semua presenter.

\section{HASIL DAN PEMBAHASAN}

$\begin{array}{ll}\text { Terdapat } & \text { tiga } \\ \text { perbandingan yang dilihat dari }\end{array}$ presentasi para subjek. Pertama adalah perbandingan komunikasi nonverbal gerak tubuh antara penutur asli dan penutur asing Bahasa Inggris dalam berbicara di depan hadirin. Kedua, perbandingan komunikasi nonverbal ekspresi wajah antara penutur asli dan penutur asing Bahasa Inggris dalam berbicara di depan hadirin. Dan ketiga, perbandingan komunikasi nonverbal kontak mata antara penutur asli dan penutur asing Bahasa Inggris dalam berbicara di depan hadirin. Berikut ini adalah data penelitian yang disampaikan dalam tiga sub judul.

Dalam rangka melihat perbandingan komunikasi nonverbal gerak tubuh antara penutur asli dan penutur asing Bahasa Inggris dalam berbicara di depan hadirin, terdapat tiga fokus pengamatan yaitu gerak kepala, gerak bahu, gerak badan, dan gerak tangan. Kalau dilihat dari frekuensi gerakan yang terjadi, dapat ditunjukkan data seperti pada tabel 1 berikut. 
Tabel 1.Perbandingan Frekuensi Komunikasi Nonverbal Gerak Tubuh Subjek

\begin{tabular}{|l|c|c|c|c|c|c|}
\hline \multicolumn{1}{|c|}{$\begin{array}{c}\text { Jenis Kom. } \\
\text { NonVerbal }\end{array}$} & \multicolumn{7}{|c|}{$\begin{array}{c}\text { Subjek Penutur Asli } \\
\text { (frekuensi) }\end{array}$} \\
\hline & 1 & 2 & 3 & 4 & 5 & Total \\
\hline Gerak Kepala & 50 & 45 & 60 & 57 & 63 & 275 \\
\hline Gerak bahu & 2 & 1 & 2 & 1 & 1 & 7 \\
\hline Gerak badan & 45 & 48 & 62 & 60 & 69 & 284 \\
\hline Gerak tangan & 70 & 85 & 84 & 74 & 57 & 370 \\
\hline & \multicolumn{6}{|c|}{ Subjek Penutur Asing (frekuensi) } \\
\hline Gerak Kepala & 20 & 15 & 16 & 17 & 16 & 84 \\
\hline Gerak bahu & 0 & 0 & 0 & 0 & 0 & 0 \\
\hline Gerak badan & 2 & 4 & 7 & 5 & 4 & 22 \\
\hline Gerak tangan & 12 & 15 & 18 & 16 & 13 & 74 \\
\hline
\end{tabular}

Pada tabel 1 dapat dilihat bahwa dalam berpidato, setiap subjek menunjukkan frekuensi yang beragam dalam penggunaan gerak tubuh yang meliputi gerak kepala, gerak bahu, gerak badan, dan gerak tangan. Secara umum, sebagaimana juga ditemukan oleh Huang (2011) subjek penutur asli menunjukkan frekuensi yang lebih tinggi pada setiap aspek.Mereka hampir selalu menggerakkan bagian-bagian tubuh mereka ketika berbicara. Sebaliknya penutur asing menunjukkan frekuensi yang lebih rendah dari keseluruhan aspek pengamatan. Pada temuan ini terdapat kemiripan temuan Suandi (2010). Penutur asing lebih sering berbicara saja tanpa disertai oleh gerakan bagian tubuh lain. Gerakan tubuh ini selain membantu untuk mengekspresikan makna, juga berfungsi sebagai ekspresi perasaan pembicara sendiri (self-expression) sebagaimana juga ditemukan Thomson (2014).

Dari aspek gerakan kepala, antar penutur asli menunjukkan frekuensi yang berbeda, namun secara rata-rata jauh lebih tinggi dari frekuensi penutur asing. Penutur asli selalu menggerakkan kepala ketika menoleh ke hadirin tertentu, membagi perhatian kepada semua hadirin supaya tidak terpaku pada satu titik, menekankan suatu hal, dan menjaga kedinamisan penampilan sehingga kelihatan lebih tenang dan menguasai panggung. Mereka melakukan gerakan tersebut dengan alami, sehingga tidak terkesan kaku dan dibuat-buat.Sehingga setelah dihitung frekuensi gerakan kepala semua penutur asli adalah 275 kali. Kemudian di lain pihak, penutur asing menunjukkan frekuensi yang jauh lebih rendah, kurang dari setengah frekuensi penutur asli. Penutur asing lebih jarang menggerakkan kepala ketika berbicara. Terdapat kecenderungan bahwa mereka lebih sering terpaku pada suatu kelompok hadirin yang biasanya kelompok dominan atau mereka yang berada tepat di depan pembicara. Setiap subjek penutur asing, sebagaimana subjek penutur asli, menunjukkan frekuensi beragam dalam menggunakan gerakan kepala sebagai bahasa nonverbal mereka dalam berpidato. Setelah dihitung, total frekuensi gerakan kepala oleh subjek penutur asing adalah 84 kali.Kemudian untuk lebih jelasnya, perbandingan 
frekuensi komunikasi nonverbal gerakan kepala antara kedua kelompok subjek penelitian dapat dipresentasikan pada gambar 1 berikut.

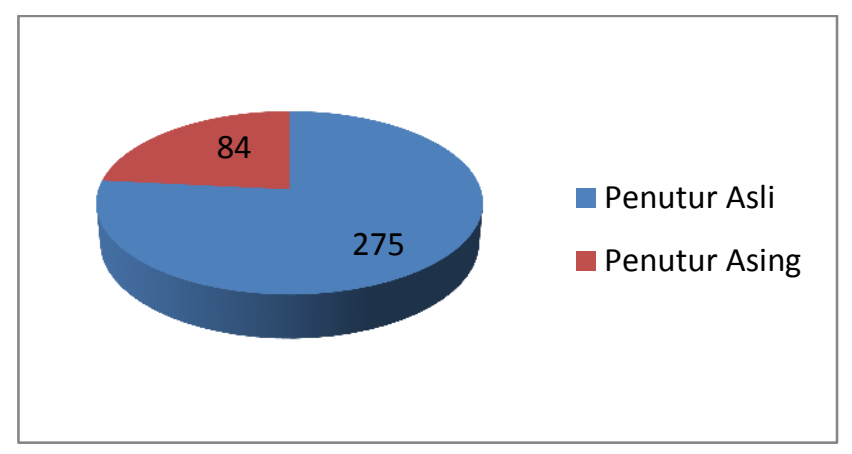

Gambar 1. Perbandingan Frekuensi Komunikasi Nonverbal Gerak Kepala Subjek

Dalam gambar 1 di atas terlihat dengan jelas perbandingan frekuensi gerak tubuh penutur asli dan penutur asing dalam berpidato. Penutur asli menunjukkan 275 kali gerakan kepala $(76,6 \%)$ dibandingkan dengan penutur asing (23,4\%). Perbedaan frekuensi tersebut bisa disebabkan oleh beberapa faktor antara lain: a). faktor budaya, b). faktor pemahaman teks pidato, c). faktor pengalaman berbicara di depan umum, d) faktor keahlian pembicara terhadap bidang yang dipresentasikan, dan e). faktor perbedaan situasi acara di mana pidato disampaikan.

Kemudian setelah gerakan kepala, elemen kedua yang diobservasi adalah gerak bahu.Gerakan bahu yang dimaksud adalah mengangkat bahu yang menunjang makna ujaran.Dibandingkan dengan gerakan kepala, gerakan bahu relatif jauh lebih jarang ditunjukkan oleh subjek.Setelah dihitung, subjek penutur asli menggunakan gerakan bahu sebanyak 7 kali dan penutur asing tidak menggunakan gerakan bahu.Gerakan bahu ini, oleh penutur asli, digunakan apabila menunjukkan suatu keprihatinan dan keraguan terhadap suatu hal yang dikombinasikan dengan membuka telapak tangan atau memiringkan kepala dan gerakan mulut dengan bibir terkatup.Subjek penutur asli semuanya menggunakan gerakan bahu dalam presentasi mereka walaupun frekuensinya beragam.Kemudian, subjek penutur asing tidak menunjukkan gerakan bahu ketika berpidato. Untuk lebih jelasnya, perbandingan frekuensi gerakan bahu oleh penutur asli dan penutur asing dapat dilihat pada gambar 2 berikut. 


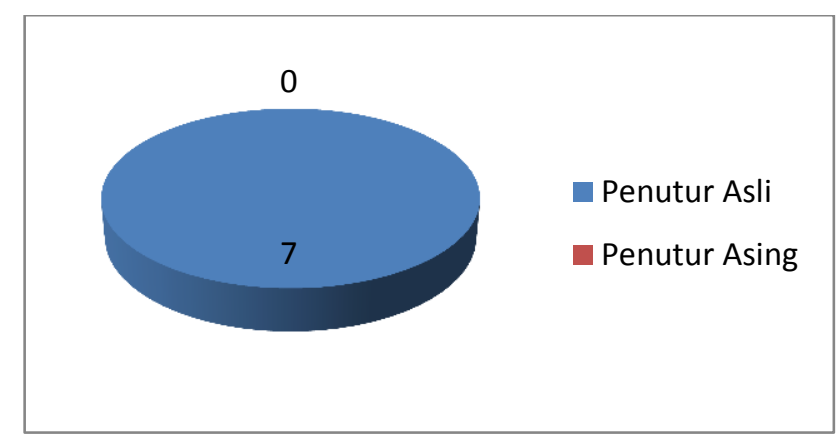

Gambar 2. Perbandingan Frekuensi Komunikasi Nonverbal Gerak Bahu Subjek

Seperti frekuensi penggunaan gerakan kepala, frekuensi gerak bahu masih didominasi oleh penutur asli. Penutur asli melakukan gerakan bahu sebanyak 7 kali (100\%) sedangkan penutur asing melakukan gerakan bahu sebanyak 0 kali $(0 \%)$.Secara kultural, penutur asing memang memiliki suatu gestur gerakan bahu yang biasa mereka gunakan dalam berbicara, baik percakapan maupun presentasi.Dalam budaya Bali atau Indonesia, gerakan bahu sangat jarang dilakukan oleh pembicaranya. Hal inilah yang menyebabkan bahwa penutur asing bahasa Inggris yang dalam hal ini berlatar belakang budaya Bali jarang melakukan gerakan mengangkat bahu ketika berbicara.Gerakan bahu ini membuat presentasi yang disampaikan oleh penutur asli lebih dinamis daripada presentasi yang dilakukan oleh penutur asing walaupun hal tersebut banyak dipengaruhi oleh faktor budaya.

Aspek pengamatan komunikasi nonverbal selanjutnya adalah gerak badan.Yang dimaksud dengan gerak badan adalah segala gerakan tubuh diluar kepala, tangan, dan wajah yang dilakukan secara sadar oleh pembicara dalam presentasi.Gerak badan yang paling dominan terlihat adalah gerak ke arah kanan dan kiri yang dilakukan
pembicara.Kalau dilihat pada tabel 1, total gerak badan penutur asli adalah 284 kali.Kalau dibandingkan antar penutur asli, terdapat variasi frekuensi gerak badan, sebagaimana yang dilakukan oleh penutur asing.Namun secara umum penutur asli Bahasa Inggris menunjukkan frekuensi gerak badan yang jauh lebih tinggi daripada penutur asing.Penutur asli kelihatan jauh lebih dinamis dalam presentasi karena gerak badan ini.Mereka sangat menguasai panggung yang menunjukkan mereka sangat menguasai topik dan bahasa pengantar yaitu Bahasa Inggris.Kalau para mahasiswa, mereka bukanlah orang yang sangat berpengalaman dalam berbicara di depan umum sehingga mereka masih harus menyesuaikan diri dengan hadirin, topik yang dibawakan dan bahasa pengantar pidato tersebut.Keadaan ini secara tidak langsung membuat mereka terlihat lebih tegang dan sulit untuk tampil natural.Hal tersebut menyebabkan mereka hanya menunjukkan frekuensi gerak badan 22 kali dalam berpidato. Bahkan subjek 1 sangat jarang dalam menggerakkan badan mereka, bahkan hanya 2 kali. Subjek tersebut terlalu terpaku dengan arah depan yang dianggap arah yang dominan. Ketika mereka harus 
mempertahankan kontak mata dengan hadirin, mereka tidak menggerakkan badan dalam menoleh ke kelompok hadirin tertentu tetapi hanya menggerakkan kepala saja.Hal yang jauh berbeda terlihat pada subjek dari kelompok penutur asli.Mereka selalu menggerakkan badannya sesuai dengan arah kepala sehingga hampir setiap ujaran disertai dengan gerakan badan. Hal tersebut mengakibatkan frekuensi gerakan kepala dengan gerakan badan hampir sama jumlahnya. Untuk melihat perbandingan frekuensi gerak badan antara penutur asli dan penutur asing Bahasa Inggris, perlu diperhatikan gambar 3 berikut.

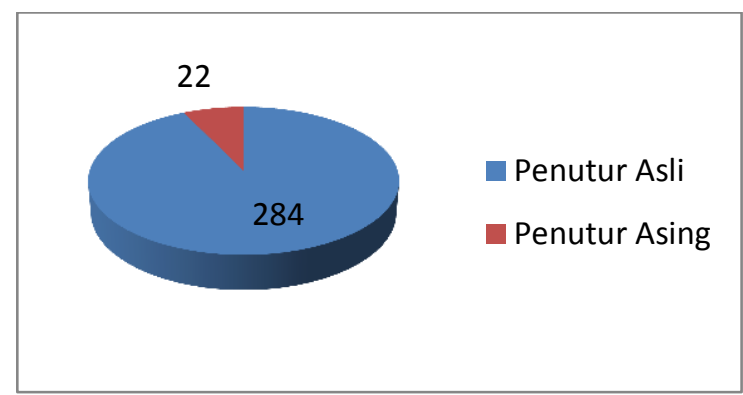

Gambar 3. Perbandingan Frekuensi Komunikasi Nonverbal Gerak Badan

Gambar 3 menunjukkan bahwa
frekuensi penutur asli dalam menggerakkan badan dalam berpidato jauh kebih tinggi dari frekuensi gerak badan penutur asing. Penutur asli melakukan gerak badan sebanyak 284 kali $(92,81 \%)$ sedangkan penutur asing melakukan 22 kali gerak badan (7,19\%).Sama seperti aspek-aspek presentasi sebelumnya, kualitas pembicara menentukan kedinamisan presentasi yang dilakukan.

Aspek pengamatan selanjutnya sehubungan dengan gerak tubuh adalah gerak tangan.Gerak tangan merupakan aspek yang sangat dominan dalam komunikasi nonverbal yang mendukung komunikasi verbal Bahasa Inggris.Gerak tangan yang dimaksud dalam hal ini meliputi gerak lengan, gerak tangan (telapak tangan dan jari).Secara budaya, perbedaan persepsi antara penutur asli Bahasa Inggris dengan orang Bali, membuat perbedaan yang tinggi dalam penggunaan gerak tangan dalam presentasi.Seperti yang disampaikan pada tabel 1 terlihat bahwa frekuensi gerak tangan antara penutur asli dan penutur asing sangat berbeda. Jumlah total frekuensi penutur asli adalah 370 sedangkan jumlah gerakan tangan penutur asing adalah 74 kali. Selain itu, penutur asli menunjukkan variasi gerakan tangan yang lebih beragam daripada penutur asing.Gerakan tangan penutur asli tidak monoton seperti yang dilakukan penutur asli, yang hanya bergerak seadanya.Penutur asli hampir selalu menggerakkan tangannya ketika melakukan aktivitas verbal.Setiap makna verbal sangat ditekankan dengan gerakan tangan sehingga makna verbal menjadi semakin jelas.Supaya lebih jelas, perbandingan frekuensi gerak tangan dapat dilihat pada gambar 4 berikut. 


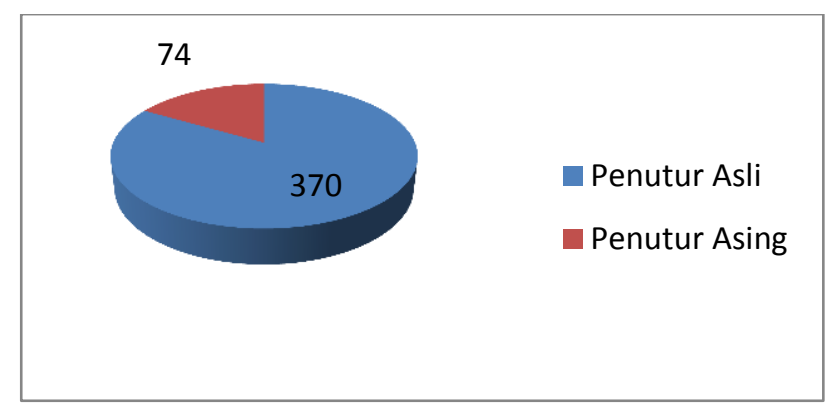

Gambar 4. Perbandingan Frekuensi Komunikasi Nonverbal Gerak Tangan

Gambar 4 di atas menunjukkan bahwa terdapat 370 kali gerak tangan yang dilakukan oleh penutur asli atau $83,33 \%$. Sedangkan penutur asing melakukan gerak tangan sebanyak 74 kali atau $16,66 \%$. Perbandingan ini menunjukkan bahwa frekuensi penggunaan gerak tangan dalam berbahasa Inggris oleh penutur asli sangat tinggi, jauh lebih tinggi dari frekuensi penggunaan tangan oleh penutur asing. Hal ini juga berhubungan erat dengan perbedaan budaya barat dan budaya Bali yang menghindari terlalu banyak menggerakkan anggota tubuh termasuk tangan ketika berbicara karena bisa dianggap melakukan gerakan yang berlebihan.Terlihat juga bahwa subjek penutur asing terlalu sering mengandalkan aspek verbal saja dalam menyampaikan suatu maksud.

Permasalahan penelitian kedua adalah tentang perbandingan komunikasi nonverbal ekpresi wajah antara penutur asli dan penutur asing Bahasa Inggris dalam public speaking. Ekspresi wajah yang dimaksud dibagi menjadi dua aspek pengamatan yaitu: mengernyitkan dahi, dan ekspresi sesuai makna kata. Data hasil penelitian disampaikan dalam tabel 2 berikut.

Tabel 2. Perbandingan Frekuensi Komunikasi Nonverbal Ekspresi Wajah

\begin{tabular}{|l|c|c|c|c|c|c|}
\hline \multicolumn{1}{|c|}{ Jenis } & \multicolumn{7}{c|}{ Subjek } \\
\hline & 1 & 2 & 3 & 4 & 5 & Total \\
\hline Kom. NonVerbal & 2 & 0 & 1 & 0 & 0 & 3 \\
\hline Mengernyitkan dahi & 15 & 13 & 14 & 10 & 9 & 61 \\
\hline & \multicolumn{7}{|c|}{ Subjek Penutur Asing } \\
\hline Mengernyitkan dahi & 0 & 0 & 0 & 0 & 0 & 0 \\
\hline Ekspresi sesuai makna kata & 2 & 3 & 2 & 1 & 2 & 10 \\
\hline
\end{tabular}


Mengernyitkan dahi merupakan ekspresi wajah yang relatif jarang dilakukan oleh kedua kelompok subjek. Dari 5 subjek penutur asli terdapat dua subjek saja yang melakukan gerakan ini, dan frekuensinya pun tidak terlalu sering. Kelompok penutur asli ini hanya menunjukkan frekuensi 5 kali dalam mengernyitkan dahi. Ekspresi wajah sebenarnya sangat penting dalam menyampaikan pesan, emosi, dan aspek budaya, ataupun status sosial pembicara (Zhan, 2012). Di lain pihak, kelompok penutur asing sama sekali tidak melakukan gerakan ini sehingga frekuensi mereka adalah 0. Gerakan kernyitan dahi ini ditunjukkan ketika menunjukkan perasaan keprihatinan atau perasaan sejenis yang dikombinasikan dengan tarikan nafas panjang. Dan untuk melihat lebih jelas perbandingan frekuensinya, dapat dilihat dalam gambar 5 .

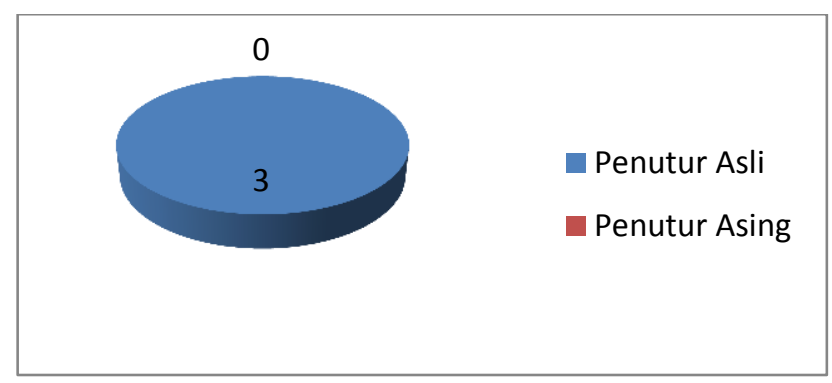

Gambar 5. Perbandingan Frekuensi Komunikasi Nonverbal Kernyitan Dahi

Gambar 5 menunjukkan bahwa semua mengernyitkan dahi dalam berbicara. Secara total hanya terdapat 3 kali (100\%) kernyitan dahi yang muncul yang semuanya dari penutur asli. Hal tersebut menunjukkan bahwa penutur asli lebih bisa merasakan makna pragmatis dari isi pembicaraan yang bisa menunjukkan keprihatinan, atau tidakterdapatnya ide untuk sesuatu masalah.

Kemudian aspek penelitian difokuskan pada ekspresi wajah yang menekankan makna kata atau ujaran. Secara umum penutur asli lebih ekspresif dari penutur asing. Sehingga terlihat dari tabel 2 bahwa total frekuensi ekpresi wajah adalah penutur asli adalah 61 kali dan total frekuensi penutur asing adalah 10 kali. Dalam hal ini terlihat bahwa penutur asli lebih bisa merasakan makna ujaran yang mereka sampaikan sehingga ekpresi wajahnya pun lebih sesuai dengan ujarannya. Penutur asing terlihat sebaliknya, masih belum bisa merasakan makna pragmatis ujaran yang mereka sampaikan. Untuk melihat lebih jelasnya perbandingan ekpresi wajah dapat dilihat dalam gambar 6 . 


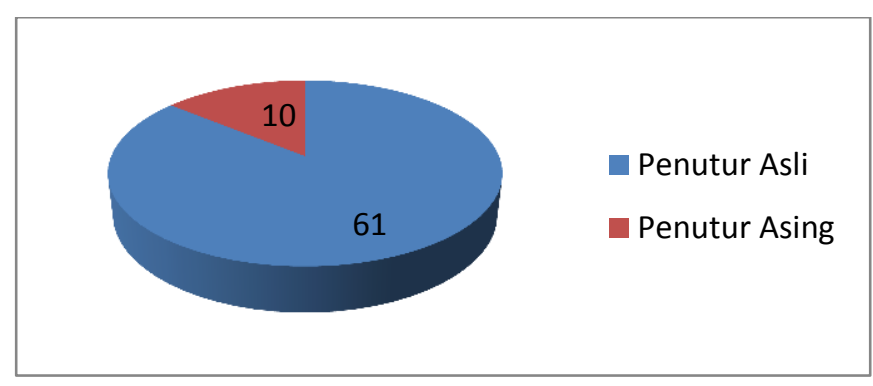

Gambar 6. Perbandingan Frekuensi Komunikasi Nonverbal Ekspresi Wajah

Gambar 6 menunjukkan perbandingan antara frekuensi penutur asli dan penutur asing dalam menunjukkan ekspresi wajah (serius, kecewa, senang/senyum, tegas, menekankan sesuatu). Frekuensi penutur asli adalah 61 kali $(85,91 \%)$ dan frekuensi perubahan ekspresi wajah penutur asing adalah 10 kali $(16,39 \%)$. Hasil perbandingan tersebut berhubungan dengan beberapa hal antara lain; pengalaman berbicara di depan hadirin, pemahaman masalah yang disampaikan, sense bahasa penutur asli, persepsi budaya penutur baik asli maupun asing Bahasa Inggris.

Pada bagian ini, fokus pengamatan adalah perbandingan kontak mata yang diklasifikasikan: kontak mata fokus ke hadirin tertentu, melayangkan pandangan ke semua hadirin, pandangan kosong tanpa fokus ke arah langit-langit, lantai, luar ruangan dsb. Sehubungan dengan hal tersebut, data penelitian ini disampaikan pada tabel 3 berikut.

Tabel 3. Perbandingan Frekuensi Komunikasi Nonverbal Kontak Mata

\begin{tabular}{|l|c|c|c|c|c|c|}
\hline \multicolumn{1}{|c|}{ Jenis } & \multicolumn{7}{c|}{ Subjek } \\
\hline & \multicolumn{7}{|c|}{ Kom. NonVerbal } & 1 & 2 & 3 & 4 & 5 & Total \\
\hline Kontak mata fokus ke hadirin tertentu & 16 & 14 & 17 & 12 & 10 & 69 \\
\hline Melayangkan pandangan ke semua hadirin & 10 & 9 & 11 & 14 & 12 & 56 \\
\hline Memandang ke arah kosong & 0 & 0 & 0 & 0 & 0 & 0 \\
\hline & \multicolumn{5}{|c|}{ Subjek Penutur Asing } \\
\hline Kontak mata fokus ke hadirin tertentu & 12 & 14 & 20 & 12 & 10 & 68 \\
\hline Melayangkan pandangan ke semua hadirin & 6 & 5 & 7 & 2 & 4 & 24 \\
\hline Memandang ke arah kosong & 1 & 0 & 2 & 1 & 3 & 7 \\
\hline
\end{tabular}

Kontak mata dengan hadirin tertentu sudah dilakukan oleh kedua kelompok subjek dengan frekuensi yang hampir sama walaupun masih didominasi oleh subjek penutur asli. Dalam aspek budaya, terdapat perbedaan mencolok antara budaya barat dan budaya Bali tentang persepsi kontak mata dengan lawan bicara. Budaya barat menyatakan bahwa kontak mata merupakan suatu keharusan sebagai tanda bahwa orang yang terlibat dalam komunikasi memberikan perhatian atau antusias terhadap lawan bicara atau topik yang dibicarakan.

Selain 
mempertahankan kontak mata bisa menunjukkan penghargaan atau penghormatan terhadap lawan bicara. Di lain pihak, budaya Bali tradisional sedikit berbeda dengan persepsi orang barat terhadap kontak mata. Orang Bali mungkin akan menganggap lawan bicara tidak sopan ketika harus memandang mata lawan bicara. Namun dalam penelitian ini ditemukan bahwa penutur asli dan penutur asing Bahasa Inggris menunjukkan frekuensi yang tidak jauh berbeda. Penelitian yang dilakukan oleh Ducasse (2013) di Spanyol, menemukan bahwa tatapan mata memiliki signifikansi yang sama dengan gestur. Penelitian itu dilakukan dalam konteks budaya barat sehingga hasilnya berbeda dengan penelitian yang dilakukan Suandi (2010) yang dilakukan pada masyarakat Bali yang menganut budaya timur yang cenderung tidak straight to the point. Walaupun subjek penutur asing sudah mempelajari teknik berbicara di depan umum dalam style budaya barat, pengaruh budaya timur masih terlihat. Hal itu ditunjukkan oleh perbedaan frekuensi yang ditampilkan pada tabel 3. Untuk lebih jelasnya perbandingan kontak mata antara penutur asli dan penutur asing dapat dilihat pada gambar 7 berikut.

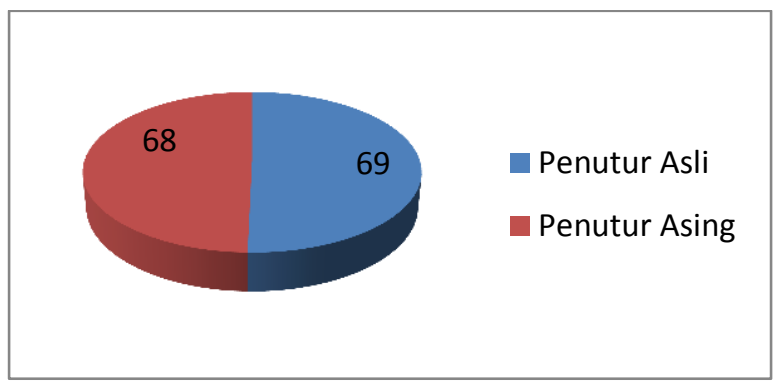

Gambar 7. Perbandingan Frekuensi Komunikasi Nonverbal Kontak Mata ke Hadirin Tertentu

Gambar 7 menunjukkan perbandingan yang hampir seimbang antara penutur asli dan penutur asing. Hal ini menunjukkan bahwa kedua kelompok subjek memiliki pemahaman yang sama terhadap pentingnya kontak mata dalam berbicara Bahasa Inggris.

Tabel 3 juga berisi data tentang melayangkan pandangan tanpa fokus tertentu atau melayangkan pandangan ke semua hadirin. Gerakan ini biasanya dilakukan ketika pembicara ingin membagi perhatian ke semua hadirin karena tidaklah mungkin hanya berfokus pada sekelompok hadirin tertentu. Pada tabel 3 disampaikan, bahwa penutur asli lebih sering menggunakan pandangan yang berfokus kepada semua hadirin. Perbandingannya dapat dilihat dalam gambar 8 berikut.

Jurnal IImu Sosial dan Humaniora|701 


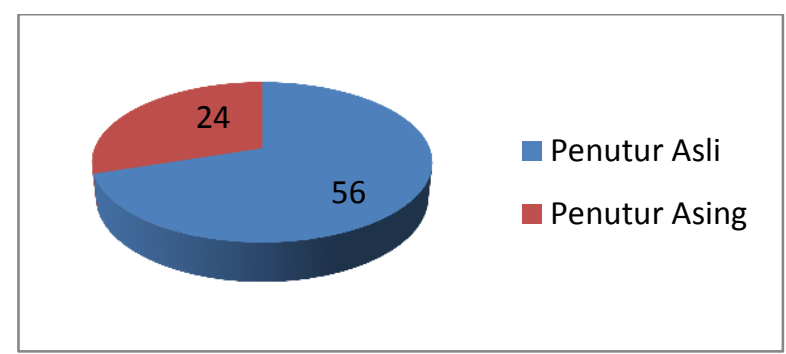

Gambar 8. Perbandingan Frekuensi Komunikasi Nonverbal Melayangkan Pandangan ke semua Hadirin

Gambar 8 menunjukkan bahwa penutur asli melakukan pandangan ke semua hadirin sebanyak 56 kali $(70 \%)$ dan frekuensi penutur asing adalah 24 kali $(30 \%)$. Keaktifan penutur asli dalam melayangkan pandangan mata ke semua hadirin disebabkan oleh pengalaman mereka dalam berbicara di depan hadirin sehingga mereka bisa menguasai panggung dengan baik.

Aspek pengamatan yang terakhir adalah pandangan ke arah kosong yang dilakukan oleh kedua kelompok pembicara. Dalam aspek ini data berbeda dari data sebelumnya ditemukan. Pada data sebelumnya, frekuensi gerakan komunikasi nonverbal selalu didominasi oleh penutur asli namun dalam aspek ini, penutur asing lebih sering melakukannya walaupun tidak dalam frekuensi yang tinggi (lihat tabel 3). Untuk melihat perbandingan frekuensi antara penutur asli dan penutur asing, dibuatlah gambar 9 berikut.

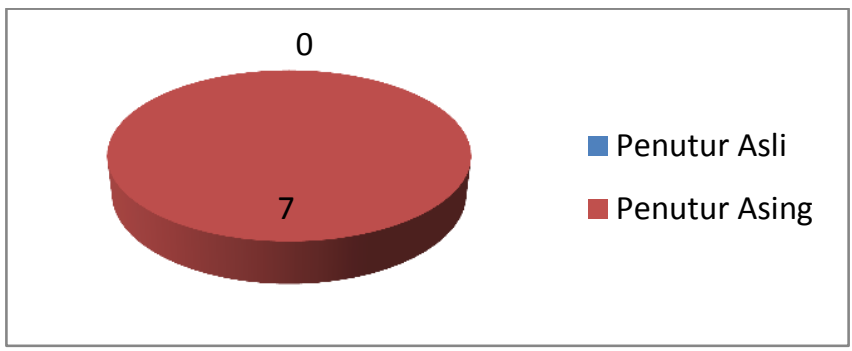

Gambar 9. Perbandingan Frekuensi Komunikasi Nonverbal Pandangan ke Arah Kosong

Gambar 9 menunjukkan bahwa
kelompok subjek penutur asing
melakukan pandangan kosong
sebanyak 7 kali, sedangkan kelompok
subjek penutur asli tidak melakukannya.
Menurut subjek penutur asing, mereka
sesekali melihat ke ruang yang kosong
untuk mengingat sesuatu atau

memvariasikan pandangan supaya tidak monoton ke suatu arah.

\section{PENUTUP}

Penggunaan Komunikasi verbal dan non-verbal dalam public speaking saling berhubungan. Penutur asing Bahasa Inggris menunjukkan frekuensi yang lebih tinggi dari penutur asingnya dalam 
penggunaan aspek nonverbal dalam public speaking. Temuan penelitian ini sejalan dengan Penelitian Suandi (2010) yang menemukan bahwa terdapat sejumlah responden yang menanggapi negatif penggunaan gerak gerik lawan bicara. Kedua kelompok subjek menunjukkan bahwa gerak tubuh dan pandangan mata merupakan aspek nonverbal mutlak dalam publik speaking. Hal ini sejalan dengan temuan Ducasee (2013) yang juga menyatakan hal yang sama. Namun dalam konteks public speaking terdapat faktor lain yang mempengaruhi yaitu pengalaman tampil di depan publik, pemahaman isi pidato, tingkat penguasaan topik dan bahasa pengantar.

\section{UCAPAN TERIMA KASIH}

Terima kasih disampaikan kepada Universitas Pendidikan Ganesha khususnya Lemlit Undiksha yang telah memberikan kesempatan untuk pelaksanaan dan pembiayaan penelitian ini. Kemudian ucapan terima kasih juga disampaikan kepada para peneliti dan ahli yang karyanya dipakai sebagai referensi ataupun menunjang pelaksanaan penelitian ini. Kami juga menyampaikan terima kasih kepada pengelola website WWW.TED.COM yang sudah menyediakan sumber data yang sangat bagus. Dan tidak lupa kami menyampaikan apresiasi kepada para mahasiswa yang dijadikan subjek penelitian.

\section{DAFTAR PUSTAKA}

Ducasee, A. M. 2013. Such a Nice Gesture: Paired Spanish Interaction in Oral Test Discourse. Journal of Language Teaching and
Research, Vol.4, No.6, 1167-1174. doi: 10.4304/j Itr.4.6.1167-1175

Gao, H. 2013. On the Cultivation of Cross-culture Communication Competence of Second Language Learners. Theory and Practice in Language Studies. Vol. 3, No. 8, 1429-1433.

doi:10.4304/tpls.3.8.1429-1433

Huang, L. 2011. Nonverbal Communication in College English Classroom Teaching. Journal of Language Teaching and Research, Vol. 2, No.4, pp. 903908. doi: 10.4304/j Itr.2.4.903-908.

Miguel, J. \& Dols, F.2013. Advances in the Study of Facial Expression: An Introduction to the Special Section. Emotion Review Vol. 5, No. 1, 3-7. doi: $10.1177 / 1754073912457209$

Mulyana, Y. G. H. 2007.A Practical Guide English ForPublic speakingRevisi. Jakarta: Kesaint Blanc

Suandi, I. N. 2010. Strategi Memadukan Komunikasi Verbal dan Nonverbal.Orasi Pengenalan Jabatan Guru Besar. Singaraja: Universitas Pendidikan Ganesha.

Sutopo, H.B. 2006. Metodologi Penelitian Kualitatif. Surakarta : UNS

Tian, J. 2010. A Comparative Study of Chinese and American Cultural Context and the Influence on Communication. Journal of Language Teaching and Research. Vol.1. No. 4. 524-526, doi: 10.4304/j Itr.1.4.524-526.

Thomson, J.M. 2014. Teachers' Perceptions of Other Teachers' Spontaneous Hand Gesturing in the EFL Classroom. Novitas Royal (Research on Youth and Language), Vol 8 (2), 119-135.

Jurnal IImu Sosial dan Humaniora |703 
Zhan, L. 2012. Nonverbal Communication in Pride and Prejudice. Theory and Practice in
Language Studies, Vol. 2, No.8, 1621-1626, doi: tpls.2.8.1621-1626. 